\title{
In Defense of Native Literature: Writers' Associations, State and the Cult of the Writer in pre-1945 Bulgaria
}

\section{Irina Gigova}

In the early 2000s, literary scholar Andrew Wachtel brought to light the struggles of writers in post-communist eastern Europe to "remain relevant." In this "part of the world where serious literature and those who produce it have traditionally been overvalued," he observed the fading of a historical "cult of national literature in general and of national poets in particular" in the face of political pluralism and market forces. ${ }^{1}$ Seeking to bring attention to the creative strategies of contemporary Russian and east European writers, Wachtel uncritically reiterated an idealized liaison between literature and nation. His opening chapter-“The Writer as a National Hero"-drew a direct and continuous line between nineteenth-century cultural nation-building and the privileged position of writers in the communist era.

I question this assumed unique position of writers in eastern Europe by looking at Bulgaria in the first half of the twentieth century. Recent scholarship has reminded us that there was nothing east European about the veneration of poets in the 1800s. A European-wide cult of the poet, a bequest of both Enlightenment admiration for great minds and Romantic awe for gifted individuals, led to numerous public commemorations of men such as Petrarch, Walter Scott, and Adam Mickiewicz. ${ }^{2}$ Yet these celebrations did not translate into a respect or income for contemporary writers. In fact, the crises of literature and the arts, now commonly associated with the post-1989 restructuring of post-communist societies, plagued the region long before the Second World War. In response to adverse circumstances and attentive to wider trends in Europe and the United States, Bulgarian novelists, poets, and critics (just like artists and musicians) sought ways to solidify their social position. Professional organizing became vital to promoting original belleslettres and securing authors' legal and financial status. But in the context of an impoverished interwar society under the swell of mass media and entertainment, unionization was not enough. Writers and their associations sought various strategies and means (not always literary) to enhance their visibility. I propose that the myth of "the writer as a national hero" was a deliberate creation by social actors seeking to correct an unsatisfying social reality, not an expression of an organic relationship between nation and writers (and intellectuals more broadly). ${ }^{3}$

1. Andrew Baruch Wachtel, Remaining Relevant after Communism: The Role of the Writer in Eastern Europe (Chicago, 2006), 4, 12, 15, 26.

2. Joep Leerssen and Ann Rigney, eds. Commemorating Writers in Nineteenth-Century Europe: Nation-Building and Centenary Fever (New York, 2014), 1-16; Marijan Dović and Jón Karl Helgason, National Poets, Cultural Saints: Canonization and Commemorative Cults of Writers in Europe (Leiden, 2017).

3. For example, Miroslav Hroch, Social Preconditions of National Revival in Europe: A Comparative Analysis of the Social Composition of Patriotic Groups among the Smaller 


\section{The International Milieu}

Although the focus of this study is Bulgaria, the story told here is of cultural producers responding to the disruption of their world in the years between the world wars. ${ }^{4}$ The "crisis of the [European] mind" identified by Paul Valéry in 1919 was comprehensive and, as he expected, long-lasting. Its immediate roots were in the Great European War, which shook the foundations of the European order. The disorientation was particularly strong in the eastern half of continent, where the rise of new states from the ashes of the vanquished Habsburg, Ottoman, and Russian empires, the expansion or diminution of existing Balkan countries, and the need to integrate populations or heal the wounds of defeat prompted vicious debates over identity and politics. ${ }^{5}$ Disenchantment with the nineteenth-century liberal order and the violent clash of "old" and "new" in Russia, Italy, and Germany stimulated not only political but aesthetic experimentations throughout the continent. Caught in this maelstrom, artists, writers and musicians feverishly tested various forms to reflect new realities-from expressionist and folkish art to agitprop and socialist realism. ${ }^{6}$

The postwar cultural crisis, however, also had deeper technological and institutional causes that probed the very merits of traditional arts. If late nineteenth-century public education had contributed to "an unprecedented phenomenon, a mass reading public" for novelists and poets, "the development of cinema, telephone, and wireless, audio-visual communication was ready

European Nations (New York, 2000); Ronald Grigor Suny and Michael D. Kennedy, eds. Intellectuals and the Articulation of the Nation (Ann Arbor, 1999).

4. I eschew the terms "intellectuals" and "intelligentsia" that have long and contested histories. My focus on associational life is served better by the professional designation of "writer” or Pierre Bourdieu's “cultural producer," in The Rules of Art: Genesis and Structure of the Literary Field, trans. Susan Emanuel (Stanford, 1996).

5. Among many, Robert Gerwarth, The Vanquished: Why the First World War Failed to End (New York, 2016); Maria Bucur, Eugenics and Modernization in Interwar Romania (Pittsburgh, 2002); Marius Turda and Paul J. Weindling, eds., Blood and Homeland: Eugenics and Racial Nationalism in Central and Southeast Europe, 1900-1940 (Budapest, 2007); Paul Hanebrink, In Defense of Christian Hungary: Religion, Nationalism, and Antisemitism, 1890-1944 (Ithaca, 2006); Eva Plach, The Clash of Moral Nations: Cultural Politics in Piłsudski's Poland, 1926-1935 (Athens, OH, 2006); Marci Shore, Caviar and Ashes: A Warsaw Generation's Life and Death in Marxism, 1918-1968 (New Haven, 2006); Irina Livezeanu, Cultural Politics in Greater Romania: Regionalism, Nation Building and Ethnic Struggle, 1918-1930 (Ithaca, 1995); Ivo Banac and Katherine Verdery, eds., National Character and National Ideology in Interwar Eastern Europe (New Haven, 1995); John Lampe and Mark Mazower, eds., Ideologies and National Identities: The Case of Twentieth-Century Southeastern Europe (Budapest, 2004); Diana Mishkova, Marius Turda, and Balázs Trencsényi, eds., Discourses of Collective Identity in Central and Southeast Europe (17701945): Texts and Commentaries, Vol. IV. Anti-modernism - Radical Revisions of Collective Identity (Budapest, 2014).

6. On cultural trends, see Ivan T. Berend, Decades of Crisis: Central and Eastern Europe before World War II (Berkeley, 1998); Thomas Ort, Art and Life in Modernist Prague: Karel Capek and His Generation, 1911-1938 (New York, 2013); regretfully, Bulgaria is not represented in S.A. Mansbach, Modern Art in Eastern Europe: From the Baltic to the Balkans, ca. 1890-1939 (Cambridge, 1999) and Timothy Benson, ed. Central European Avantgardes: Exchange and Transformation, 1910-1930 (Los Angeles, 2002). 
to fetter the written word and to contest its supremacy over the imagination."'7 Finding the ground under their feet shaky, cultural producers in the 1920s reflected on their collective situation, in the process setting the groundwork of modern sociology of intellectuals. ${ }^{8}$ They faced "a situation without good choices;" the powers they had claimed since the Enlightenment to legislate morality, culture, and politics increasingly fell to state institutions or consumer society. ${ }^{9}$ Those that found this situation distasteful retreated to the coves of the university or the esoteric realm of modernism. ${ }^{10}$ Others heeded the siren calls of mass state ideologies, either to the left or to the right, leading Julien Benda to famously decry in 1927 "the treason of the intellectual." ${ }^{11}$ Many shared José Ortega y Gasset's anxieties about the rise of the "mass-man" and "mass culture."12 Georges Duhamel's 1937 Défense des lettres and its gloomy forecast for the book's future in a society regaled by sports, radio tunes, and movies resonated widely precisely because it expressed already entrenched sentiments. While critics vilified American music and film, thoughtful observers worried that technological modernity itself assailed national uniqueness and depreciated the arts. ${ }^{13}$

The shifting sands of cultural production and consumption brought more than laments and experiments. The first decades of the century saw a renewed push toward professional organization in the arts. While studies of modern high culture (focused on trends, circles and figures) rest on "silences" about the institutional or economic underbelly of intellectual activities, in fact cultural producers have always fretted about money. ${ }^{14}$ As early as 1838 , French writers such as Honoré de Balzac, Alexander Dumas, Victor Hugo, and George Sand founded the Société des gens de lettres de France to defend the legal rights of authors. After two failed efforts to associate, a British Society of Authors emerged in 1883. Such national organizations lobbied for the 1886 Berne Convention that gave authors automatic copyrights and sought to

7. Philip Waller, Writers, Readers, and Reputations: Literary Life in Britain 1870-1918 (Oxford, 2006), 3.

8. Charles Kurzman and Lynn Owens, "The Sociology of Intellectuals," Annual Review of Sociology 28 (2002), 63-64.

9. Zygmunt Bauman, Legislators and Interpreters: On Modernity, Post-Modernity and Intellectuals (Cambridge, 1987), 124.

10. John Carey, The Intellectuals and the Masses: Pride and Prejudice among the Literary Intelligentsia, 1880-1939 (Chicago, 2002); Jeremy Jennings, "Deaths of the Intellectual: A Comparative Autopsy," in Helen Small, ed., The Public Intellectual (Oxford, 2002), 110-30. 1969).

11. Julien Benda, The Treason of the Intellectuals, trans. Richard Aldington (New York,

12. José Ortega y Gasset, The Revolt of the Masses (New York, 1960), first published in Spanish in 1930.

13. Andrei S. Markovits, Uncouth Nation: Why Europe Dislikes America (Princeton, 2007); and David Ellwood, The Shock of America: Europe and the Challenge of the Century (Oxford, 2012).

14. Michel-Rolph Trouillot, Silencing the Past: Power and the Production of History (Boston, 1995). Professional guilds are missing in the otherwise excellent four-volume series edited by Marcel Cornis-Pope and John Neubauer, eds. History of the Literary Cultures of East-Central Europe: Junctures and Disjunctures in the $19^{\text {th }}$ and $20^{\text {th }}$ Centuries (Amsterdam, 2004-2010). 
stymie international piracy. ${ }^{15}$ Writers' organizations gathered momentum in the early 1900s: from the 1912 Authors' Guild in the United States, to the pacifist international PEN Club (1921), and the not-so pacifist Nazi-led European Writers' Union of $1941 .{ }^{16}$ The Union of Bulgarian Writers was born in 1913, a Syndicate of Czech Writers came into being in 1918, and two years later Stefan Żeromski initiated the Professional Union of Polish Writers that lasted until $1939 .{ }^{17}$ The need to defend writers' professional interests also led to the Hungarian Writers' Economic Organization (1932-44).

Sociologists have long identified the push toward association as a feature of the west's growing rationalization, specialization, and bureaucratization. While the free professions (doctors, lawyers, and teachers) have been widely studied, guilds in the cultural sphere have not. ${ }^{18}$ The neglect reflects hesitancy about institutionalized culture. Could one really conflate creativity with professionalism? In addition, both interwar and Cold War politics tarnished the reputations of creative guilds. Between the wars, even the purposefully apolitical PEN International could not escape entanglements in minority politics or fascist conceptions of art. By the 1930s, Benito Mussolini's Italy and Adolf Hitler's Germany had become models of state-patronized art production that used cultural organizations and institutions to reorganize national life and challenge the European liberal order. ${ }^{19}$ After 1945, all east European creative unions were taken over (and new ones put in place) as communist regimes consolidated power. Thus it is not surprising that we associate unionization of artists and writers with Joseph Stalin's top-down "socialist realism" or Joseph Goebbels's Reich Chamber of Culture. ${ }^{20}$

15. Benedict Atkinson and Brian Fitzgerald, A Short History of Copyright: The Genie of Information (Cham, 2014); Daniel Hack, "Literary Paupers and Professional Authors: The Guild of Literature and Art," Studies in English Literature, 1500-1900, 39, no. 4 (Autumn 1999): 691-713; Robert A. Colby, "Authors Unite!: An Anglo-American Alliance, Victorian Periodicals Review 26, no. 3 (Fall 1993): 125-32."

16. R. A. Wilford, “The PEN Club, 1930-50," Journal of Contemporary History 14, no. 1 (1979): 99-116; Andrea Orzoff, "Prague PEN and Central European Cultural Nationalism, 1924-1935," Nationalities Papers: The Journal of Nationalism and Ethnicity 29, no. 2 (2001): 243-65; Benjamin George Martin, “'European Literature' in the Nazi New Order: The Cultural Politics of the European Writers' Union, 1941-3,” Journal of Contemporary History 48, no. 3 (2013): 486-508.

17. Lumír Čivrný, “Good and Bad Times: Seventy Years of the Czech PEN Club,” in Literature and Tolerance: Views from Prague (Prague, 1994), 25-76.

18. George Ritzer, "Professionalization, Bureaucratization and Rationalization: The Views of Max Weber," Social Forces 53, no. 4 (June 1975): 627-34. More recently, Konrad Jarausch, The Unfree Professions: German Lawyers, Teachers and Engineers, 1900-1950 (New York, 1990); Charles E. McClelland, The German Experience of Professionalization: Modern Learned Professions and their Organization from the Early Nineteenth Century to the Hitler Era (Cambridge, 1991); Maria M. Kovacs, Liberal Professions and Illiberal Politics: Hungary from the Habsburgs to the Holocaust (Washington, 1994); Elliott A. Krause, Death of the Guilds: Professions, States, and the Advance of Capitalism, 1930 to the Present (New Haven, 1996).

19. Benjamin G. Martin, The Nazi-Fascist New Order for European Culture (Cambridge, Mass., 2016).

20. Alan E. Steinweis, Art, Ideology, and Economics in Nazi Germany: The Reich Chamber of Music, Theater, and the Visual Arts (Chapel Hill, 1993); Michael H. Kater, The Twisted Muse: Musicians and Their Music in the Third Reich ( New York, 1997); D. Medina Lasansky, 
Taken on their own terms, however, cultural associations were efforts to restore the autonomy of intellectuals as value-creators in a world of state centralization and market powers. Elliott Krause sees guilds as an expression of the professional desire to have "power and control over the association, the workplace, the market, and the relation to the state." ${ }^{21}$ Writers could use their organizations as a mark of public recognition, to defend their vocational interests, to seek state assistance against unfavorable markets or resist official censorship. Their actual accomplishments depended on the specific triangulation of associations, state politics and market forces. As Mabel Berezin has shown, interwar states were particularly active as cultural actors. They could subsidize cultural products (for example, the "cultural protectionism" of the United States' 1935 Works Progress Administration that "served as a state sponsored market correction mechanism"), could organize cultural producers without controlling their work (the "state paternalism" of fascist Italy), or could hold the reins of both cultural producers and their work (Stalinist Russia and Nazi Germany). Naturally, associations could not envision the direction their efforts would take. For example, the 1921 Italian Society of Authors' (founded in 1882) economically-motivated cozying upto the state unexpectedly led to writers' loss of autonomy when a Fascist regime came to power the following year and reorganized culture. ${ }^{22}$

In the following pages I employ a sociological approach focused on relations, practices and institutions rather than literary discussions of identity to show how the Bulgarian writer emerged as a "national hero" in the interwar years. Without further research, I dare not claim the process unfolded similarly elsewhere, but the factors that enabled the Bulgarian myth of the writer were not exclusive to that country: 1) increased professionalization of cultural production; 2) postwar interest in culture as a political tool; 3) economic pressure by wars, the Great Depression, and the spread of mass culture that prompted cultural producers to turn to the state, and 4) ability to attach the figure of the author to potent historical narratives. By the late 1930s, elevated rhetoric about native literature's historical value became common as writers, politicians, and public figures found it mutually beneficial to glorify the native book and its creators. This collaboration laid the foundations for both the reorganization of the cultural field by the communist authorities after the Second World War and the widespread popular and scholarly claims about writers' contributions to nation building and ethnic survival.

\section{Rise of the Professional Writer}

Three decades after Bulgarians gained self-rule in 1878, writing was hardly a reputable vocation and no authors made a living from their pen. In a country where $80 \%$ of the 4.34 million inhabitants were rural in 1910, cultural

The Renaissance Perfected: Architecture, Spectacle and Tourism in Fascist Italy (University Park, 2004).

21. Krause, Death of the Guilds, 3.

22. Mabel Berezin, "The Organization of Political Ideology: Culture, State, and Theater in Fascist Italy,” American Sociological Review 56, no. 5 (October 1991): 648. 
circles were eclectic. Members of the liberal professions wrote poems and critiqued theater performances, musicians and artists dabbled in art criticism, and everyone was a journalist. Important literary periodicals, such as Misŭl (Thought, 1882-1907), covered philosophy, political trends, and aesthetics, in addition to literary criticism and original prose or poetry. While urban literacy was high (61\% among ethnic Bulgarians in 1910, and $71.2 \%$ for men), it remained low (33.3\%) in the countryside and among most minorities except Jews and Armenians. Bulgarian culture on the eve of the wars was predominantly urban, ethnically Bulgarian, and male. It also remained small. The 1910 census listed 5,724 men and 362 women in the creative professions (literati, architects, and artists). Even if one included teachers (nearly 14,500 in 1910), the overall number of Bulgarian cultural producers and consumers was insignificant and undifferentiated. ${ }^{23}$

The seeds of professionalization in Bulgarian cultural life can be seen in the founding of Sofia University (1888), the Art School (1896), the National Theater (1904), and the Bulgarian Academy of Sciences and Arts (1911). Itinerant merchants gave way to formal publishers, such as Ivan Ignatov (1862-1937) and Todor Chipev (1867-1944), who built large bookstores in Sofia in the early 1890s, creating public spaces for the distribution of literature. ${ }^{24} \mathrm{At}$ the turn of the century ideas began to circulate about an organization to promote literature's standing. That all early and short-lived societies combined writers and journalists indicated the nebulous separation of these groups. ${ }^{25}$ Contemporaries agreed that Bulgarian society was unable to support professional writers prior to the wars. Low literacy rates, a tiny middle class, and readers' preferences for sensationalist, translated works restricted the market for both classical western works and original Bulgarian belles-lettres. Honorariums were uncommon; only translations and editing earned remuneration and original books appeared in limited editions. ${ }^{26}$ And while Bulgarian literacy rates were higher than in neighboring Romania, one is tempted to share Alex Drace-Francis' observation that vernacular literature could not play the unifying role famously ascribed to it by Benedict Anderson. ${ }^{27}$

There was also no unitary vision of writers' social role. The Union of Bulgarian Writers was born in early September 1913, in the wake of Bulgaria's defeat, territorial losses, and international dishonor in the Second Balkan War. The timing has led Bulgarian scholars to see its birth as a sign of writers'

23. Statisticheski godishnik na bŭlgarskoto tsarstvo (1929-1930), 14, 22, 36-39. 160-70.

24. Ani Gergova, Knizhninata i bŭlgarite: XIX-nachaloto na XX vek (Sofia, 1991),

25. Kalinka Anchova, "Sŭzdavane na sŭiuza na bŭlgarskite pisateli prez esenta na 1913 g. v arhivni dokumenti i spomeni na ochevidtsi," Izvestiia na dŭrzhavnite arhivi, no. 65 (1993): 197-227; Georgi Drŭndarov, Nikola Atanasov, Hristo Ts. Borina, Georgi Karaivanov, Istoriia na sŭiuza na bŭlgarskite pisateli, 1913-1944 (Sofia, 2003), 8-16.

26. Gergova, Knizhninata, 175-76, 195-207; Konstantin Konstantinov, Pŭt prez godinite (Sofia, 1966).

27. Diana Mishkova, "Literacy and Nation-building in Bulgaria, 1878-1912," East European Quarterly 28, no.1 (1994); 63-93; Alex Drace-Francis, The Making of Modern Romanian Culture: Literacy and the Development of National Identity (London, 2006); Benedict Anderson, Imagined Communities: Reflections on the Origins and Spread of Nationalism (London, 2006). 
patriotism, an extension of their wartime service. ${ }^{28}$ This explanation does not fit the founders' purely professional stated goals: to secure writers' financial well-being, promote their unity, find a broader readership and higher social esteem for their works, and aid those in dire financial need. ${ }^{29}$ The nineteen initiators were not the famous literati of the day. While they immediately reached out to another fifty-four individuals (including five women), internal conflicts hindered the Union's solidification. A founder and critic Nikola Atanasov (1877-1947) recalled in the early 1930s that until the First World War writers "were instigated by individualist sentiments and rejected the collective principle in the name of the complete independence of the creator." Material discomforts were seen as an artist's destiny; preoccupation with material concerns seemed philistine. ${ }^{30}$ Aesthetic and generational differences further drove a wedge into the community. Many of the young modernist poets dismissed the Union's founders as authors of cookie-cutter prose and poetry in trite forms and timeworn language. ${ }^{31}$ Still others found the Union's readiness to exact state support distressing, and instead advocated public outreach and more enticing literature. In short, no consensus existed that a professional organization was needed.

The Great War changed both circumstances and attitudes. The mobilization of many writers as wartime correspondents after 1915, the year Bulgaria entered the conflict on the Central Powers' side, solidified their professional identity. In Bulgaria, as elsewhere, the First World War was represented, consumed, and understood through literary means. ${ }^{32}$ The Army's General Staff used Bulgarian arts and literature to raise troop and civilian morale. The military journal Otechestvo (Fatherland, 1914-18) and newspaper Voenni izvestiia (Military News, 1892-1919) recruited well-known figures, while their expanding network of contributors turned newcomers into household names. More importantly, Bulgarian authors for the first time enjoyed a large readership. By 1917, Otechestvo's runs of 25,000-30,000 surpassed those of many daily newspapers and dwarfed the prewar Misŭl's circulation of 1,000-2,000. ${ }^{33}$

The wars also gave birth to a generation keen on literature. The "Field Library for Soldiers" was a joint initiative of the General Staff and a commission of professors and writers. It created regimental libraries and distributed

28. Rumiana Koneva, Goliamata sreshta na bŭlgarskiia narod: Kulturata i predizvikatelstvata na voinite, 1912-1918 g. (Sofia, 1995); Velichko Georgiev, Bŭlgarskata inteligentsia i natsionalnata kauza v Pŭrvata svetovna voina: Sŭiuzŭt na bŭlgarskite ucheni, pisateli i khudozhnitsi, 1917-1918 (Sofia, 2000); Evelina Kelbetcheva, "Between Apology and Denial: Bulgarian Culture during World War I," in Aviel Roshwald and Richard Stites, eds., European Culture in the Great War: The Arts, Entertainment, and Propaganda, 1914-1918 (Cambridge, 1999), 215-42.

29. Drŭndarov et al., Istoriia na sŭiuza, 42-58.

30. Nikola Atanasov, quoted in Anchova, "Sŭzdavane," 200, 216.

31. "Literaturni belezhki, novini, i pr.," Zveno no. 4-5 (1914), 160-63.

32. Shafquat Towheed and Edmund King, eds. Reading and the First World War: Readers, Texts, Archives (New York, 2015).

33. Bŭlgarski periodichen pechat, 1844-1944: Anotiran bibliografski ukazatel, vol. 1 (Sofia, 1962), 477, 480. 
some fifty titles, mostly by Bulgarian authors, in pocket-book format. ${ }^{34}$ Literate soldiers wrote poetry, short stories, and plays for new field theaters to "kill the boredom" of trench life; illiterate ones enrolled in army-sponsored reading classes. Front letters and diaries filled with allegories and literary images confounded censors. ${ }^{35}$ Youth on the home front, avid readers of the military publications, held even more promise as consumers of literature. Literacy rates among the draftees in the universal labor service established after the war were 92\% among ethnic Bulgarians, with 23.9\% having gymnasium education and above in $1923 .{ }^{36}$ Public libraries in Sofia and Plovdiv grew dramatically in both patrons and volumes read between 1920 and 1925, with notable increases in student, artisan, laborer, and office worker visits. While many used the libraries to follow domestic and world events-the peace conference, the Russian civil war, and political turmoil at home-the popularity of Bulgarian-language belles-lettres grew steadily in the 1920s, reversing previous preferences for Russian, French, and German works. ${ }^{37}$

While the war promoted the professionalization of writers and increased their audience, it also drew writers' attention to the country's suffering. As a result of the punitive 1919 Treaty of Neuilly, Bulgaria lost lands, population, and its army in return for thousands of refugees. It was forced to pay reparations estimated at $22.5 \%$ of its prewar national wealth and faced with international enmity. Political radicalization pushed out King Ferdinand (1861-1948) in favor of his son Boris (1894-1943), and brought the Bulgarian Agrarian National Union to power with plans for a new order that would work for the silent peasant majority. ${ }^{38}$ The general morass mobilized intellectuals into action. As early as 1917, some 150 prominent authors, scientists, and artists had joined efforts to advocate Bulgarian interests abroad. ${ }^{39}$ After the disheartening peace, musicians, artists, actors, and literati hoped to revive public dignity through immediate contact with the people in the form of public lectures, exhibits, and recitals. ${ }^{40}$

The Writers' Union also returned to active life in 1919 with literary readings to honor fallen comrades and build good will toward its mission. It soon doubled its membership, drawing on both new faces and those who had spurned the association in 1913-14. Yet, centrifugal forces continued to undercut ambitions to organize the literary field. Many writers appealed to their brethren to reside among the people and generate art that resonated

34. Koneva, Goliamata sreshta, 89-93, 98-99; Kelbecheva, "Between Apology and Denial," 219-22.

35. Snezhana Dimitrova, “'Taming the Death': The Culture of Death (1915-18) and its Remembering and Commemorating through First World War Soldier Monuments in Bulgaria (1917-44)," Social History 30, no. 2 (May 2005), 177-84.

36. Statisticheski godishnik na bŭlgarskoto tsarstvo (1926), 95.

37. Statisticheski godishnik na bŭlgarskoto tsarstvo (1928), 423.

38. R. J. Crampton, Bulgaria (Oxford, 2007), 210-24; R. J. Crampton, Aleksandur Stamboliiski, Bulgaria: Makers of the Modern World, The Peace Conferences of 1919-23 and Their Aftermath (London, 2009).

39. Georgiev, Bŭlgarskata inteligentsiia.

40. Sofia Vasileva, Sŭiuz na druzhestvata na khudozhnitsite v Bŭlgariia: Predistoriia, organizatsiia i deinost, 1919-1945 (Sofia, 2012), 43-53. 
with their daily struggles. ${ }^{41}$ What that meant in practice split the community into numerous (and fluid) circles associated with specific publications and editors: Vezni (Scales, 1919-22), Zlatorog (Golden Horn, 1920-44), Razvigor (1921-27), Hiperion (1922-31), Strelets (Archer, 1927), and Bŭlgarska misŭl (Bulgarian Thought, 1925-43). While some advocated German expressionism and diabolism, others turned towards "native art" (rodno izkustvo), combining avant-garde and folk motives. ${ }^{42}$ The left, energized by Bolshevik Russia, stood in opposition to all these "bourgeois" trends. A new "left generation" abandoned the "decadent poetry" of the prewar years for realist works and communist ideas, and sought its own publications, critics, and associations. ${ }^{43}$

\section{State Search for a "Usable” Culture}

The feverish competition of these literary circles for readers' attention and loyalty occurred against the backdrop of shifting and unstable official attitudes toward culture and its producers. The "national catastrophes" of the Balkan and First World Wars cast doubt on the nineteenth-century national ideals-autonomous church, schooling, and a large Bulgaria on the borders of the 1878 San Stefano Treaty-and on the institutions that had championed them: the church, the army, and the monarchy. In this vacuum, culture and the arts became a viable tool of social integration and nation building. ${ }^{44}$ This was especially the case under the Bulgarian Agrarian National Union (BANU), brought to power in 1919 by an electorate hostile to the old royalist and military elites. As most modern political regimes, BANU sought a "usable past" to promote its agenda. The period that best fit its values of citizen initiative, selfless dedication, and work against all odds was the nineteenth-century Bulgarian National Revival, a period of cultural and national "awakening." 45

As the Revival (Vŭzrazhdane) has a part in the following narrative, it is worth outlining its traits. With analogues throughout the empires of eastern and central Europe, its Bulgarian start is commonly dated to 1762, when a Mount Athos monk named Paisii Hilendarski wrote the first modern history of medieval Bulgaria. His Slavonic Bulgarian History exhorted readers $111-13$.

41. Emanuil p. Dimitrov, "Poziv kŭm bŭlgarskiia pisatel,” Ognishte 1, no. 2 (1919),

42. Charles A. Moser, A History of Bulgarian Literature, 865-1944 (The Hague, 1972), 181-250; Svetlozar Igov, Istoriia na bŭlgarskata literatura (Sofia, 2002), 613- 786; Irina Genova and Tatiana Dimitrova, Izkustvoto v Bŭlgariia prez 1920-te godini: Modernizŭm i natsionalna ideia (Sofia, 2002). For regional developments, see Keith Hitchins, Rumania 1866-1947 (Oxford, 1994), 292-334.

43. Ivan Meshekov coined the phrase in his semi-autobiographical Liavo pokolenie ot gimnaziiata do okopite, 1907-1917 (Sofia, 1934). On leftwing literature, see Zheliu Avdzhiev, Esteticheskoto tŭrzhestvo na sotsialisticheskata literatura, 1919-1923 (Sofia, 1975).

44. Emil Dimitrov, Pamet, iubilei, kanon: Uvod v sotsiologiiata na bŭlgarskata literatura (Sofia, 2012), 36-80.

45. On the idea of moral rebirth in the 1920s, see Plach, The Clash. On the Revival, see Roumen Daskalov, The Making of a Nation in the Balkans: Historiography of the Bulgarian Revival (Budapest, 2004); Maria Todorova, Bones of Contention: The Living Archive of Vasil Levski and the Making of Bulgaria's National Hero (Budapest, 2009); more broadly Hroch, Social Preconditions; Wachtel, Remaining Relevant, 12-43; Ivan T. Berend, History Derailed: Central and Eastern Europe in the Long Nineteenth Century (Berkeley, 2003), 41-82. 
to stop emulating the Greeks and seek inspiration in the glory of their own past. Paisii's message and manuscript were picked up in the 1840s by activists seeking to "awaken" the Ottoman-ruled Bulgarian nation. These "awakeners" (buditeli) were clergymen, revolutionaries, merchants, and educators who agitated for Bulgarian autonomy. And while many became state builders after 1878, the overall contributions of the awakeners drew so little public attention that in the early 1880s the up-and-coming poet and writer Ivan Vazov (1850-1921) composed a cycle of odes to key Revival figures, entitled Epic of the Forgotten. The young Bulgarian monarchy preferred an identity rooted in "the glorious history of the two medieval Bulgarian empires" and favored monuments and festivities that praised Bulgarian military prowess, not cultural achievements. ${ }^{46}$

The defeats of 1913 and 1918 undermined faith in military solutions and heightened the appeal of the romantic martyrdom, democratic ideals, and cultural work of the "awakeners." It was not accidental that the Writers' Union mourned its wartime losses and the punitive Neuilly Treaty in late 1919 with a Revival-inspired show at the National Theater called "Apotheosis of the Bulgarian Word.” By employing actors to impersonate and read the writings of Paisii, revolutionary poet Hristo Botev (1848-1876), the revered Ivan Vazov and others, the Writers' Union laid a claim to a literary tradition of national service and perseverance. ${ }^{47}$ This activist spirit appealed to the BANU Ministry of Education, which collaborated with the Union and two public committees in organizing a country-wide celebration of the seventy-year-old Vazov in 1920. Hailed as Bulgaria's "spiritual leader" and "national poet," Ivan Vazov became its first postwar hero; after his death in 1921, the Ministry commissioned a museum and bust in Sofia's central park to immortalize "the patriarch of Bulgarian literature, the great bard of the Bulgarian land." 48

The Vazov celebrations inaugurated a period of heightened state attention to literature and the arts under the banner of the Revival. Under BANU, the Ministry of Education engaged academics, artists and literati in articulating policies that promoted a democratic view of Bulgarian culture. Some initiatives were symbolic. A new national holiday, the Day of People's Awakeners (Den na narodnite buditeli) began on November 1, 1922; parades, public lectures, and readings at school and church were held aimed to revive virtues presumably destroyed by the wars (patriotism, idealism, civic duty) and to generate a "cult of the Bulgarian national genius." The Ministry assisted citizen committees seeking monuments to "the national apostles of the epoch of

46. Claudia Weber, “'Opiti za sŭzhiviavane’: Kŭm nachalata na bŭlgarskata kultura na pametta," Balkanistichen forum, no. 1-3 (1999), 158-66; Albena Hranova, "Historian Myths: the Bulgarian Case of Pride and Prejudice," in Pål Kolstø, ed., Myths and Boundaries in South-Eastern Europe (London, 2005), 297-324; and Todorova, Bones of Contention, 221-27.

47. Khristo Ts. Borina, writing in 1933, claimed the performance's public success inspired the Day of National Awakeners discussed below. Drŭndarov et al., Istoriia na sŭiuza, 29.

48. Dimitrov, Pamet, iubilei, kanon, 62-136; Stilian Chilingirov, ed. Pomen za Ivana Vazov: sbornik za traurnite chestvuvaniia na narodniia poet ot 22 do 28 septemvri 1921 god (Sofia, 1922); TsDA (Central State Archive), f. 177k (Ministry of National Education), op. 1, a.e. $876,11.30,60$. 
the Revival and Liberation." ${ }^{\prime 9}$ Living "awakeners" were also honored: some 1,500 composers, writers, journalists, artists, publishers, professors, and school officials-and 3,000 teachers-received awards..$^{50}$ Of greater impact to the cultural field were the Ministry's practical measures. Between 1920 and 1923 it simplified orthography, expanded the educational and library system into rural areas to increase literacy, doubled the years of mandatory schooling, and broadened access to professional education. It expanded funding for museums, created several new universities and academies of art, and promoted scientific research. It adopted the first copyright law (following the Berne Convention) and mandated deposits of new books into public libraries. Finally, the 1921 Law for the Promotion of Native Literature and Art aimed to support domestic talent through state-sponsored publications or competitions, subsidies to institutions and individuals, purchases of literary and artistic works, and annual awards and stipends for specialization abroad. ${ }^{51}$

BANU's heavy-handed, uncompromising approach, however, alienated many, even educators and literati. A military coup in early June 1923 led to the brutal murder of BANU's leader Alexandŭr Stamboliiski and the arrest and exile of many of his supporters. A new government, led by professor of political economy Alexandŭr Tsankov (1879-1959), came to power with promises of national unity but was remembered for its conflict with agrarians and communists that brought the country to the brink of civil war. The cultural community hardly felt loved after the coup. The government reversed or underfunded many of BANU's initiatives, tightened censorship, and attacked opponents. Several left-wing poets and journalists critical of the regime disappeared. As efforts to find them failed, the Writers' Union was attacked by the left for its association with a "fascist" regime. ${ }^{52}$ Cooperation with the Ministry of Education increasingly became a liability. Its annual awards, established with the 1921 law, regularly sparked accusations of favoritism and partisanship in the distribution of state funding. ${ }^{53}$

Tsankov resigned in January 1926 and a moderate National Alliance government came to power (until 1931) with the goal of refurbishing Bulgaria's reputation abroad and renegotiating the crippling reparation payments. More conservative than the Agrarians, at home the regime invoked traditional patriotic values to promote social harmony. Its Ministry of Education mandated singing the national anthem in schools, stressed religious and history instruction, and even banned Esperanto in 1928 for fear of the youth's "de-nationalization." 54 It also allied with young King Boris, who had been

49. Stoian Denchev and Sofia Vasileva, Dŭrzhavna politika za kulturno-istoricheskoto nasledstvo na Bŭlgariia, 1878-2009 (Sofia, 2010), 181-82; Dimitrov, Pamet, 166-81. On citizen committees, see TsDA, f. 177k, op. 1, a.e. 876, 1l. 1-30; op. 2, a.e. 196, 287 and 668, 11. 105-78.

50. Vasileva, Sŭiuz na druzhestvata, 48; Aleksandŭr Velev, Prosvetna i kutlurna politika na pravitelstvoto na Aleksandŭr Stamboliiski (Sofia, 1980), 168-89.

51. Crampton, Bulgaria, 224-36 and Velev, Prosvetna i kutlurna politika.

52. Drŭndarov et al., Istoriia na sŭiuza, 122-23.

53. For example, “Nagradite za literatura i izkustvo," Zlatorog 7, no. 2-3 (1926), 13941; V. P. "Literaturni premii," Ognishte 4, no. 1 (1926), 30-31.

54. Nikola Balabanov and Andrei Manev, eds. Sbornik s otbrani okrŭzhni ot Osvobozhdenieto do kraia na 1942 (Sofia, 1943), 617-19, 712-20. 
mostly ignored by previous governments. To embody these new priorities, the Ministry of Education planned a nation-wide celebration of a major triple anniversary: a millennium of King Simeon's Golden Age (893-927), half a century of independence, and a decade of Boris's reign. Moving closer in policies to the "conservative stabilization" of István Bethlen's Hungary, an isolated and weakened Bulgaria desired to showcase its grand history and old culture to the world. 55

If BANU's 1920 appropriation of Ivan Vazov had focused the nation's eyes on literature and the poet, the 1929 triple anniversary curtsied to the monarchy. Planned for 1928 but delayed by a destructive earthquake, festivities began on May 12, 1929 and attracted international attention. ${ }^{56}$ As their echoes reverberated into the early 1940s in ways discussed below, it is worth dwelling on their symbolism. The jubilee began with a "pilgrimage" of thousands of Bulgarians, headed by the young monarch with state and church dignitaries, to the town of Preslav, Simeon's tenth-century capital. After a military parade, a thanksgiving mass, and a feast for 5,000 "Bulgarian patriots," King Boris exhorted all parties to "subordinate their political differences to the higher national interest of unity and solidarity which has held the nation together since the reign of Czar Simeon." Boris then set fire to a pyre of wood from Simeon's birth place and runners carried this "light of freedom" to all corners of the country. In the evening 10,000 peasants dressed in tenth-century costumes serenaded the king and the cabinet. ${ }^{57}$ The symbolism linked the young ruler to the First Bulgarian Empire (erasing ties with his father, Ferdinand, blamed for the losses of 1913 and 1918), while his pilgrimage alongside commoners democratized him. His appeal for cooperation drew on Revival ideas, as did the Ministry's reliance on grass-root activism in making the 1929 celebration a success. ${ }^{58}$ Notably, writers and cultural producers were generally nowhere in sight.

\section{The Missing Market}

While the celebrations of 1929 raised some hopes for a repetition of the medieval Golden Age of Bulgarian literature and arts, the economic realities worked against such a renaissance. The weight of reparations, inflation, and unemployment withered Bulgarians' purchasing power and frayed the inroads Bulgarian authors and books had made among readers in the early 1920s. Surveys of household spending in March 1925 showed that even the wealthiest officials or professionals spent just over one percent of their budget on periodicals, books, and theater tickets. Workers found them practically out-of-reach. A year-long study of family budgets (from June 1927 to May 1928) revealed a tiny increase in culture spending that suggested a family of modest

55. TsDA, f. $177 \mathrm{k}$, op. 2, a.e. 196, 1l. 34, 40-45, 56; scholarly treatment in Dimitrov, 232-65. On Hungary see Kovacs, Liberal Professions, 50; and Zsolt Nagy, "National Identities for Export: East European Cultural Diplomacy in Inter-War Pittsburgh,” Contemporary European History 20, no. 4 (November 2011): 435-53.

56. "Bulgaria En Fete for Ancient Glory,” New York Times, May 13, 1929, 6.

57. Ibid.; also "Peasants throng Sofia for Fetes,” New York Times, May 15, 1929, 6.

58. TsDA, f. $177 \mathrm{k}$, op. 2, a.e. 287. 
means could now afford one periodical subscription. ${ }^{59}$ While public libraries served those without means, they alone could not assure the financial longevity of literary publications. Larger publishers supported losses incurred by publishing original belles-lettres with textbooks and children's literature. ${ }^{60}$ Unable to make a living from writing, aspiring authors continued to pay the bills as teachers, professors, lawyers, clerks, or librarians. They supplemented their incomes (and reputations) through occasional translations or public lectures. ${ }^{61}$

Already in 1926 and 1927, both the daily and cultural press sounded alarms about the state of national literature: the literary press born after 1919 was on publishers' life support; public libraries reported declines in readers; many complained that sensational literature and foreign films contaminated youth's tastes. ${ }^{62}$ A 1927 Ministry of Education survey of students' reading habits confirmed such fears. One regional school inspector found that on average, middle-school children read 7.9 books a year and teenagers only 9.1. Disturbingly, teens favored foreign fiction and knew of no living Bulgarian authors. ${ }^{63}$ Some commentators faulted writers themselves for producing literature of poor quality or little relevance. Others remarked that writers, publishers, and readers were simply too poor to sustain a vibrant book market and, hence, the state had to do something.

In the politically-charged milieu of the 1920s, there was no public consensus that the Ministry of Education should intervene. Thus, when the Ministry of Education embraced a new private initiative of book exhibits-begun in 1927 in the Black Sea port of Varna to lure summer vacationers-sceptics thought that an administrative approach would kill the otherwise good idea. ${ }^{64}$ The Ministry convened a special committee of teachers, school officials, and writers', publishers', and booksellers' guild representatives and accepted its recommendation of an annual Day of the Book. Interestingly, a similar initiative of Authors' Day was started by Australian booksellers' and writers' societies in 1927 to "stimulate public interest in and appreciation of Australian writers and Australian books generally." 65 The April 1929 preparations indicated an

59. Statisticheski godishnik na bŭlgarskoto tsarstvo (1926), 286-87; (1928), 272-75; (1931), 346-47.

60. Khristo D. Brŭzitsov, Bŭlgarski knigoizdateli (Sofia, 1976); Iordan Nanchev, Stranitsi za Aleksandŭr Paskalev (Sofia, 2009).

61. Igov, Istoriia, 613-786; Pantalei Zarev, Istoriia na bŭlgarskata literaturna kritika (Sofia, 1996); Rozaliia Likova, Literaturniiat zhivot mezhdu dvete voini (Sofia, 1995).

62. Amicus Plato, "Za bŭlgarskata kniga," Mir, November 27, 1926, 1; Konstantin Gŭlŭbov, “Za bŭgarskata kniga,” Izgrev, October 10, 1926; Kiril Krŭstev,” Chitateliat misli,” Razvigor, October 9, 1926, 2; D. Dimitrov, "Za prochitnata kniga,” Razvigor, January 15, 1927, 3; Geno Dochev, "Biblioteka za naroda,” Razvigor, January 29, 1927, 6; Nik. Atanasov, "Razvrateniiat chitatel," Razvigor, May 7, 1927, 2; Ot. H. Koledarov, "Bŭlgarskata knizhnina i vnosŭt na chuzhdata u nas," Mir, April 23, 1928.

63. Tsviatko Petkov, Knigata i uchenitsite: Anketa proizvedena v Vrachanski Ucheben Okrŭg (Vratsa, 1927).

64. Vasil Stavrev, "Izlozhba na bŭlgarskata kniga v Varna,” Razvigor, February 26, 1927, 6; Todor Borov, “Den na bŭlgarskata kniga,” Bŭlgarska kniga 1, no. 4-5 (September 1930), 471-72.

65. Lesley Heath, “Society of Women Writers 1925-1935," Australian Literary Studies 21, no. 3 (2004), 367. 
effort to transform literature into a performative art of broader appeal, not unlike the scheduled fete of the monarchy. The Ministry instructed schools to hold lectures and exhibit students' and teachers' favorite works. It urged the Writers' Union to organize public readings, publishers to put together exhibits, and the press to advertise the events. ${ }^{66}$ The Day of the Book, however, did not get off to a great start. For the first few years its dates kept shifting, publishers saw no benefits in the exhibits, and the Union limited its engagement to a single-issue newspaper, Rodna Kniga (Native Book). The initiative fizzled with the Depression, which forced the government to slash funding for literacy initiatives, even the popular "Library for the Youngest," which claimed to have placed 120,000 attractive, edifying books in the hands of half a million children. ${ }^{67}$

No collective voice opposed these cuts as the Writers' Union finished the 1920s in a state of weakness, its cohesion and public reputation tarnished by group rivalries and skirmishes in the press. At its lowest point, twentyfive individuals left the organization in 1930, among them some of the popular authors of the day ${ }^{68}$ While the rift was partly interpersonal, the Union was also plagued by diverging visions of its role. One of those that left was Vladimir Vasilev (1883-1963), editor of the well-regarded journal Zlatorog and Director of the National Theater at the time. He publicly accused the leadership of unwisely pushing its members to "take a stance on social and political questions." Considering writers' differences in temperament, political and aesthetic views, he argued, the Union had to defend only economic interests such as lower paper prices, reliable copyrights, regular book purchases by public libraries, and writers' job security. ${ }^{69}$

As the organization languished, competing associations arose. ${ }^{70}$ The Bulgarian section of the International P.E.N Club (founded in 1926) began to represent the country at international congresses and sought ties with Polish, Czech, Yugoslav, and west European colleagues. ${ }^{71}$ At home, in late 1930, a dozen female authors formed the Club of Bulgarian Women Writers. Soon, a rival Union of Bulgarian Women Writers appeared, accusing both the main Union and the Club of elitism. ${ }^{72}$ In 1930, an Association of Children's Writers

66. Balabanov and Manev, Sbornik, 897-98; Drŭndarov et al., Istoriia na sŭiuza, 127, 150, 200-202.

67. A. Karaliichev, "Dve biblioteki za naroda," Sŭvremennik, October 7, 1931, 3; G. Nokov, "Detskata literatura i Ministerstvoto na prosvetata," Sŭvremennik, December 9, 1931, 4.

68. “Iz pisatelskiia sŭiuz,” Zlatorog 11, no. 3 (1930), 182.

69. “Literaturen post: Kŭde e Pisatelkiiat sŭiuz?” Sŭvremennik, October 21, 1931, 1; also Vladimir Vasilev's archive in TsDA, f. 373k, op. 1, a.e. 283, 1. 16.

70. Kalinka Anchova, "Kulturno-profesionalnite sdruzhenia na khudozhestvenotvorchestkata inteligentsiia v obshtestveno-politicheskiia zhivot na Bŭlgariia (19341935)," Izvestiia na dŭrzhavnite arkhivi, no. 62 (1991): 5-41.

71. Vladimir Polianov, "Oshtestvoto na narodite na literaturna pochva," Razvigor, October 9, 1926, 1.

72. Irina Gigova, “The Feminisation of Bulgarian Literature and the Club of Bulgarian Women Writers,” Aspasia 2 (2008): 91-119. 
came into being with its own journal and events. ${ }^{73}$ The left organized the shortlived Union of Proletarian Writers (1931) and Militant Labor Writers (1932), whose publications launched one attack after another on their "bourgeois" brethren. Literati living outside the capital city (mainly teachers) indicted the Union of snubbing their needs and formed an alternative Union of Provincial Writers in March 1934 to promote the "cultural-educational advancement of the national masses." 74 To top this associational spurt, 1934 also saw the emergence of a Guild of Historical Writers.

The surge of associations suggested an awareness of the benefits of professional organizing in an unfavorable market and reflected an international trend toward "neocorporatism" during the depression years. ${ }^{75}$ With a collective voice, Unions could lobby publishers and the public, organize events, solicit state funds and private donations, distribute awards, and aid members in need. At the same time, the fragmentation of writers limited their influence. Advocates of the Writers' Union feared that divisions also "undermined the prestige of the Bulgarian writer." ${ }^{76}$ Starting in 1931, the records of the organization show a steady effort to mend relations within the community, establish a regular line of communication with the Ministry of Education, and enhance the public image of the Bulgarian writer through a series of public celebrations of well-regarded authors. ${ }^{77}$ The Union's message of unity and writers' importance began to resonate more broadly as another political regime came to power with calls for a new National Revival.

\section{The New “Awakeners"}

In Bulgaria as elsewhere, the global economic crisis and resurging irredentism fed the move of right-wing parties toward the political center stage. On May 19, 1934, a military coup led a coalition to power that articulated a technocratic vision of social and political order. While influenced by Italian corporate fascism, the regime also tapped the language of National Revival, not unlike the calls for healing and rejuvenation (sanacija) in Józef Pilsudski's Poland. In this iteration, the Revival became a metaphor for cultural confidence, social cohesion, and national vitality. The new government sidestepped BANU's emphasis on democratization in the early 1920s and promised to eliminate the disunity of party politics, bring direction to economic and social life, and promote patriotism. ${ }^{78}$ During its six-month existence, the regime banned all

73. By 1935, it had 76 members (63 men and 13 women) and more funds than the Union's roughly 100 members. TsDA, f. 142k (Asen Raztsvetnikov), op. 1, a.e. 124.

74. It had some 80 members by 1937. National Literary Museum (NLM), Inv. no. $1273 / 85,1274 / 85,1285 / 85,1286 / 85,1287 / 85$.

75. Steinweis, Art, Ideology, 17-20, Martin, The Nazi-Fascist New Order, 26-32.

76. Drŭndarov et al., Istoria na sŭiuza, 154.

77. Ibid., 153-261.

78. Plach, The Clash; Berend, Decades of Crisis, 330-45; Bernd J. Fischer, ed., Balkan Strongmen: Dictators and Authoritarian Rulers of South Eastern Europe (West Lafayette, 2007); Gergana Velichkova, Propaganda na fashizma v Bŭlgariia, 1922-1934 (Sofia, 2002); Nikolai Poppetrov, “Opiti za dirizhirane na kulturata v Bŭlgariia (1934-1944),” in Iskra Baeva, ed. Moderna Bŭlgariia: Sbornikv chest na 65-godishninite na profesor d-r Velichko Georgiev i akademik Ilcho Dimitrov (Sofia, 1999), 182-202. 
parties and organizations, introduced strict censorship, and sought to mobilize the masses through a new Directory of Public Renewal (Direktsia na obshtestvenata obnova). Even though the 1934 regime collapsed within a year-leaving King Boris to take over the reins of power-it bequeathed to subsequent governments the appropriation of the Revival to justify the authoritarian and nationalistic policies of the later part of the decade. It also set the discursive framework for cultural producers' claims to national importance in a steadilydeteriorating economic climate.

Illustrative of the new official rhetoric was the 1935 appeal "Towards a New Revival” by medievalist Petŭr Mutafchiev. Conjuring Social Darwinist warnings of national extinction due to wartime losses, material deprivation, political factionalism, and blind emulation of foreign cultures, Mutafchiev saw only one solution: an "unconditional attachment to one's ethnos [and] readiness for sacrifices in its name." Like a new Paisii, he urged Bulgarians to revisit the idols of the past and exhorted the intelligentsia's "prodigal sons to return to the hearths of their fathers, to rekindle their smoldering flames, which only could thaw their fossilized souls and prepare them for future deeds." " The tone and message of the article exemplified the language of the 1930s right-wing, which prioritized the leading role of the nation in organizing the collective and the state. Bulgarians had lost respect for great personalities, the argument went; without idols, they had no anchors in their drifting lives.

This "accent on the role of the personality, especially the wise leaderruler, educator, religious figure," provided a unifying platform for creative associations to tout their importance. ${ }^{80}$ Newly-elected Writers' Union chairman Nikola Atanasov argued in early 1935 that Bulgarian men of letters singlehandedly transferred the national idea from the material realm of revolution and politics into the spiritual realm, and hence enabled the encounter of "the primal element of the historical Bulgarian entity with the European genius." 1 A left-wing Union member similarly emphasized writers' special (and paternal) relationship to the nation: "They know best the needs of the people and judge most reliably the problems of the historical moment." 82 Speakers at the $25^{\text {th }}$ anniversary celebration of the organization asserted that poets devoted to the betterment of the nation occupied a seat of honor among its past and present leaders, next to glorious kings and heroes. Carrying in their hearts "a divine spark," these "God-chosen" individuals strode through history "clearing the path for their lesser brothers walking behind them." 83

I need to stress the novelty in the 1930s of this lofty rhetoric regarding national writers. While hyperboles enhanced the status of writers and could protect them from political persecution, their intensity and frequency increased proportionately with writers' unrelenting struggle to make a

79. Petŭr Mutafchiev, “Kŭm novo vŭzrazhdane," Otets Paisii 8, no. 1 (1935), 3-9. On the article's reception, see Daskalov, The Making of a Nation, 228-31.

80. Poppetrov, “Opiti,” 188.

81. Nikola Atanasov, "Pisatel-obshtestveno-kulturen factor," Bŭlgarska misŭl 10, no. 3 (1935), 139-40.

82. Liudmil Stoianov, “Dŭlgŭt na pisatelite,” Chas, September 19, 1936, 3.

83. Drŭndarov et al., Istoria na sŭiuza, 296. 
living. ${ }^{84}$ Even a cursory look at the pages of the popular cultural weekly newspaper Literaturen glas (Literary Voice, 1928-1944) revealed a staggering list of grievances delineating the "death certificate of today's literature:" from old problems of expensive paper to the lure of radio, the movie theater, and the stadium. ${ }^{85}$ The actual death of several prominent writers in 1937 fostered sentiments that state negligence and public apathy had contributed to their untimely passing. ${ }^{86}$ There was a clear awareness that state support alone would not save authors as long as Bulgarians did not buy native works. The solution was to make owning and reading Bulgarian literature a fad, similar to fads in clothing and furniture. ${ }^{87}$ Literaturen glas demanded a full-fledged cult of the writer: "a cult toward the one, who synthesizes our spirit, our will, our aspiration toward sunlight." 88

Since traditional literary means had failed to generate public veneration, many authors pursued new ways to broaden their audience. The Club of Bulgarian Women Writers used the women's press to advertise teas and soirees in the capital and provincial towns. The Association of Children's Writers became known for its well-attended readings at Sofia's theaters and crèches. A growing number of individuals embraced radio broadcasting. ${ }^{89}$ Nationalized after the 1934 coup, Radio Sofia began its active life in January 1935. Until 1943 it was led by Sirak Skitnik, the pen name of Panaiot Todorov (1883-1943), a modernist artist, critic, and associate of the Zlatorog circle who encouraged all cultural producers to adapt to the needs of radio audiences..$^{90}$ A growing number of well-known poets, critics, and literary scholars lent their texts and voices to the expanding number of "radio hours" for housewives, villagers, children, workers, and later on, soldiers. They discussed new trends or names abroad, lectured on the importance of literature and the Bulgarian book, and rhymed for young listeners. ${ }^{91}$

The Writers' Union also became more innovative in its public initiatives. In early 1937, its new chairman Dobri Nemirov (1882-1945) suggested to the organization's general assembly that only public worship of the writer could reverse the unfavorable status quo. Famed for his immaculate and

84. The leader of the Guild of Historical Writers (and future chairman of the Writers' Union) Stiliian Chilingirov explicitly employed this rhetoric in 1935 when he asked the Ministry of Education for financial assistance. TsDA, f. 177k, op. 2, a.e. 710, 11. 15-18, and a.e. $711,11.51-59$.

85. Examples from Literaturen glas: M. Neiova-Genadieva, "Smŭrtniiat akt na dneshnata literatura,” December 12, 1936, 1; Vasile Khristu, "Karnavalŭt na bŭlgarskata literatura,” January 19, 1937, 1; Khr. Gandev, “Kulturata umira,” January 27, 1937, 1-2; Met. N. Marinov, “Avtor i chitatel,” November 17, 1937.

86. Three months in 1937 saw the passing of poet Mara Belcheva, humorist and translator Dimitŭr Podvŭrzachov, and novelists and playwrights Iordan Iovkov and Anton Strashimirov.

87. T. Nikolov, “Bŭlgarskata kniga,” Mir, December 11, 1934, 1.

88. Iordan Cholakov, “Bŭlgarskia pisatel v nemilost,” Literaturen glas, April 27, 1938, $1-2$.

89. Not unlike French philosophers' embrace of television from the 1950s on, Tamara Chaplin, Turning on the Mind: French Philosophers on Television (Chicago, 2007).

90. Sirak Skitnik, “Stsena i radio-stsena," Zlatorog 18, no. 1 (1937).

91. Veselin Dimitrov, Istoriia na radioto v Bŭlgariia (kraiat na XIX vek-1944), vol. 1 and especially vol. 2 (Sofia, 1994). 
gentlemanly appearance, Nemirov outlined a savvy program of what might be called "rebranding": an annual grand assembly in high society that emphasized writers' feats, press releases for literary awards, grand commemorations of deceased authors and celebrations of living ones, regular readings, "teas," and "evenings with writers" at classy locales. ${ }^{92}$ To achieve all this, however, the Union had to become more inclusive. No longer could the old practice of accepting two of forty candidates continue; a professional organization had to unify all. Under new rules, the Union welcomed fifteen new members that year and restored the membership of the Zlagorog faction that had left in 1930. It openly courted left-leaning writers (eased by the Comintern's less militant Popular Front policy) and defended interned authors even if they were not on its roster. The Union cleverly undercut (inaccurate) accusations of communist infiltration by launching a full-scale publicity campaign about writers' patriotic contributions, including an audience with the king. Finally, to raise its profile, the Union marked its $25^{\text {th }}$ Jubilee in December 1938, inviting everyone who could affect its cause: from King Boris III, his ministers, the press, all scholarly and artistic organizations, to veterans and the Church. The successful stunt quelled members' opinions that the Union should not be in the business of event planning. The press extensively covered the festive banquet, the attendance of Sofia's entire elite, the laudatory official speeches and the warm-felt greetings from around the country and foreign writers' organizations. ${ }^{93}$

With enhanced media presence, improved internal cohesion and a lucid message about literature's national importance, the Union began to speak more confidently on behalf of all Bulgarian writers. In 1938 it spearheaded a public outcry against a proposed press law that stiffened censorship, the first of many vocal expressions of the Union's position on cultural and political developments. ${ }^{94}$ While in the eyes of state and society the Union was only one of several writers' associations, its initiatives turned living writers into celebrities. Thus, when Minister of Education Bogdan Filov (1883-1945), himself a Union member, convened a large committee in 1938 to design a blueprint for revived celebrations of the Bulgarian book, the proposal envisioned writers as nothing less than modern-day "awakeners" who harnessed modern media to charm the common folk. The committee recommended annual, week-long festivities in early March (before planting season in the countryside), accompanied by broad advertising, radio talks, theater performances and newsreels, and travel discounts for audiences and speakers. ${ }^{95}$ These suggestions were incorporated into a bill for the stimulation of the Bulgarian sciences, literature, and arts that Filov's Ministry began preparing in 1939. Even though

92. TsDA, f. 551 (Union of Bulgarian Writers), op. 1, a.e. 5, 1l.1-4.

93. Drŭndarov et al., Istoria na sŭiuza, 277-308; TsDA, f. 551, op. 1, a.e. 5, 11. 35-44.

94. Drŭndarov et al., Istoria na sŭiuza, 274-76.

95. The committee included representatives of the Writers' Union, the Club of Female Writers, the Association of Children's Writers, Sofia University faculty, the unions of the periodical press, publishers, journalists, educators, and the national network of reading clubs (chitalishta). TsDA, f. 177k, op. 2, a.e. 1048, 11. 20-25, and a.e. 1173, 11. 9. There is no evidence it was influenced by the Week of the German Book celebrated since 1935 in Weimar, see Martin, The Nazi-Fascist New Order, 226. 
the bill remained in planning for several more years, the Ministry budgeted annual funding for the creative guilds and the Week of the Book. ${ }^{96}$

The start of the Second World War seemed to complete both the move of writers and literature to the center of national life and the rise of the Union as the preeminent writers' organization. Union members were a prominent presence in the euphoric days of early September 1940, when Bulgaria regained southern Dobruja from Romania as a result of the Treaty of Craiova. Thirteen well-known poets and novelists (including two women) accompanied the troops that entered Dobruja, a vivid demonstration of the mighty alliance of the pen and the sword. They gave moving speeches on the radio, took pictures with soldiers and peasants, and described their experiences in the press ${ }^{97}$ The following spring - just weeks after Bulgaria formally joined the Axis on March 1, 1941-the tone of the Week of the Book became exalted, as in effect it celebrated the acquisition of Macedonia and Thrace from Yugoslavia and Greece in April 1941. Prior to the Week, the press and the radio popularized slogans such as: "The Bulgarian language and book saved our people from extinction," "There needs to be a book by a Bulgarian author in each Bulgarian home," "The best gift for our soldier today is a book by a Bulgarian writer," and "Give our youth a native book!" 98 The grand opening ceremony featured now Prime Minister Filov, Metropolitan Neofit, Boris III's secretary, professors, former ministers, composers, artists, and writers in addition to ordinary citizens. ${ }^{99}$ The Union's Chairman, Bogdan Filov, and the new Minister of Education, Boris Iotsov (1894-1945, also a Union member), extolled the contribution of the Bulgarian book toward national reunification in their addresses. ${ }^{100}$

Literature was also at the epicenter of a five-day-long nationwide celebration of the acquisition (occupation) of the "new lands" of Macedonia and Thrace organized by the Ministry of Education. Twelve years after King Boris's 1929 pilgrimage to Preslav, on May 20, 1941, a procession of Bulgarian students and army officers returned to the town to light another torch, whose "eternal flame" was then carried across the country and presented to the monarch on May 21. From Sofia, torches were taken to the enlarged borders of the country as emblems of the sovereignty of Greater Bulgaria. The festivities culminated on May 24, the Day of Saints Cyril and Methodius, the ninth-century bothers credited with the creation of the Cyrillic alphabet. May $24^{\text {th }}$ had spontaneously emerged as a celebration of Bulgarian culture after 1850, becoming an official national holiday in 1916 . Hence, it was a suitable occasion to rejoice the incorporation of Macedonia, the brothers' assumed birth place, and it fused symbolically the medieval, nineteenth-century, and modern eras. ${ }^{101}$ That

96. TsDA, f. 551, op. 1, a.e. 5, 11. 14, 34-44.

97. NLM, Inv. No. a 1023/82; also Vladimir Polianov, “S flota kûm Balchik,” Literaturen glas, November 6, 1940, 3-4.

98. TsDA, f. $177 \mathrm{k}$, op. 2, a.e. 1517, 11. 37-38.

99. “Otkrivaneto na sedmitsata na bŭlgarskata kniga,” Dnes, April 28, 1941, 1-3.

100. "Ot Okhridskoto ezero do Cherno more i ot Dunav do Bialo more za bŭlgarskiia narod zapochva nov politeshki i dukhoven zhivot," and "Vŭzroditelnata rolia na bŭlgarskata kniga se zavŭrshi," Dnes, April 28, 1941, 1-3.

101. V. Roudometof, "Toward an Archeology of National Commemorations in the Balkans,” in Michael E. Geisler, ed., National Symbols, Fractured Identities: Contesting 
same day, male and female students from the "new lands" brought handfuls of soil from their native places to Sofia. Parading before the capital populace in colorful regional costumes, they placed the soil they carried in an elegant silver urn that was then handed to the king with a pledge of loyalty from his new subjects. ${ }^{102}$

In contrast to the 1929 fete that affirmed the monarch's belonging to the nation, the wartime festivities glorified the ability of Bulgarians to overcome adversity and to maintain cultural identity and ethnic unity through the letters. Not surprisingly, this time writers were an integral part of the festivities. A member of the Union (and former official at the Ministry), Nikola Balabanov, led the group of students carrying the "holy flame" from Preslav to the "new lands," while other authors visited Sofia's schools to talk about the work of Cyril and Methodius. On May 23, the nation's most renowned writers addressed audiences in the largest venue in Sofia-the brand new "Bulgaria Hall." On May 24, representatives of the Union had reserved seats among the officials overseeing the parade. ${ }^{103}$

The Union of Bulgarian Writers was careful not to leave the initiative entirely in state hands. Chairman Stiliian Chilingirov (1881-1962) enjoined members to donate books for the occupied territories and participate in the various celebrations in 1941. He, his predecessor Dobri Nemirov, and the popular poet Elisaveta Bagriana (1893-1991) toured Macedonia in May of 1941. For twenty days these "living Bulgarian books," in the words of Nemirov, met with locals, read to them, and spoke on Macedonian radio. Upon return, the two men hurried to share and capitalize on their impressions in compact, attractive volumes. ${ }^{104}$ In September 1941, the Union closed the symbolic circle with a well-attended observance at the grave of revered national poet Ivan Vazov on the twentieth anniversary of his death. Participants sprinkled the tomb with flowers, soil, and water from the occupied territories to the sound of Vazov's poems on Macedonia, Thrace, and Dobruja. The audience was reminded that it was Vazov who had first immortalized the selfless dedication of the Revival. By echoing the earlier, state-organized May $24^{\text {th }}$ holiday, the Vazov commemoration told spectators that nineteenth-century "awakeners," Vazov ("the greatest son of Bulgaria"), and contemporary writers all followed in the footsteps of Cyril and Methodius. ${ }^{105}$ A dozen Union members took this message to Macedonia and Thrace via readings and ceremonies honoring the poet's life and work. ${ }^{106}$ Perhaps in reward for writers' patriotism, the following year the Week of the Book was set to culminate with May 24, the Day of

the National Narrative (Middlebury, 2005), 35-59; Aneta Mihaylova, "Commemorating the Nation: The Political Uses of National Day Celebration (Some Examples from the Balkans)," Études Balkaniques 44, no. 4, (2008), 190-91.

102. TsDA, f. 177k, op. 4, a.e. 572, 1l. 32, 227-30; Evdokia Filova, Dnevnik: Mai 1939-15 avgust 1944 (Sofia, 1992), 90-91.

103. TsDA, f. 551, op. 1, a.e. 1, 1. 2; NLM, Inv. No. a 631/78.

104. Dobri Nemirov, I vechna da e!: Iz Makedoniia (Sofia, 1941); Stiliian Chilingirov, Prez Makedoniia (Sofia, 1941).

105. Angel Karaliichev, “Velikiiat Vazov,” Bŭlgarska misŭl 16, no. 7 (1941), 23.

106. "Programa za tŭrzhestvata na Ivan Vazov,” Dnes, September 20, 1941, 4; TsDA, f. 551, op. 1, a.e. 1, 11. 6-7; TsDA, f. 177k, op. 2, a.e. 1173, 1. 9, a.e. 1513, 11. 20, 22, 29, 30-32, and a.e. 1517, 1l. 5-6, 104-05. 
Cyril and Methodius, cementing the public esteem of contemporary poets and novelists. Some thirty Union members received state funding to travel to all corners of Greater Bulgaria for the festivities. ${ }^{107}$

The increased public visibility of writers during the war years did not diminish their material preoccupations. In fact, despite their claims to be modern "awakeners," writers rarely displayed self-abnegation and showed sustained excitement only when the state (or public donors) backed Union initiatives financially. This inevitably led to accusations that the Writers' Union had become money-driven. ${ }^{108}$ The Union successfully lobbied for legal measures that benefitted both individuals and the guild, such as copyrights over the works of deceased authors, mandatory lists of Bulgarian titles for libraries, increased representation of Bulgarian plays in theaters and a set percentage of the gross earnings of such performances. ${ }^{109}$ The Ministry of Education also directly supported writers financially through contributions to the Union's new retirement fund or handouts to individuals. ${ }^{110}$ More importantly, it appeared that the society as a whole now saw living writers as vital to national well-being, a marked change from public attitudes a decade before. Municipal governments, starting with Sofia's in 1938, began annual donations to the Writers' Union. By 1943, before Allied bombings disrupted the country's life, the Union hoped to receive close to 500,000 leva from local governments. In addition, more private individuals than ever before made generous donations, gifts touted in the press as proof of a new partnership between intellectuals and the people. If revenues indicated social prominence, the Union's surging finances demonstrated its rise as the premier writers' organization in Bulgaria. ${ }^{111}$

In his report to the Union's general assembly in the spring of 1943, Chilingirov proudly declared that the organization, with its 150 members, had become "a central, supreme body of the spiritual life" of the nation. Other contemporaries must have concluded likewise, as the Writers' Union was the very first creative organization the communists took over in the fall of 1944, purging perceived enemies and filling the ranks with sympathizers. ${ }^{112}$ It immediately acquired a weekly newspaper, Literaturen front (Literary Front, 1944-90), which enabled

107. TsDA, f. 177k, op. 1, a.e. 1517, 1. 104-05.

108. "Pred borbi li se namira Pisatelskiat sajuz," Svetovna ilustrovana sedmica, no. 53 (February 9, 1940), 3. See also TsDA, f. 108k, op. 2, a.e. 1366, 1. 30.

109. Drŭndarov et al., Istoriia na sŭiuza, 318-68.; TsDA, f. 551, op. 1, a.e. 1, 1. 13-14; ABAN (Archive of the Bulgarian Academy of Sciences), f. 58k, op. 1, a.e. 147.; TsDA, f. 177k, op. 4, a.e. $572,11.75-76$.

110. TsDA, f. $177 \mathrm{k}$, op. 4, a.e. 596 and 598.

111. Statistical yearbooks show dramatic increase of the Union's revenues from 26,584 lv in 1936 to 291,386 lv in 1939. In comparison, in 1939 the Club of Bulgarian Women Writers made 34,929 lv, the Association of Children's Writers-19,850 lv and the P.E.N Club2,057 lv. The 1943 Union budget projected revenue of 725,500 lv. TsDA, f. 551, op. 1, a.e. 5, 11. 94-99.

112. Natalia Hristova, “'Sotsialisticheskii realizm' i drama bolgarskogo tvortsa (seredina 40-kh-seredina 50-kh godov)," Bulgarian Historical Review 26, 1-2 (1998), 152-78; and Vladimir Migev, Bŭlgarskite pisateli i politicheskiiat zhivot v Bŭlgariia, 1944-1970 (Sofia, 2001), 9-53. 
writers to address the public directly; in 1947, the association acquired its own publishing house, just as the state began to shut down private publishers. By 1948, the Union of Bulgarian Writers became the only authors' organization, as the Club of Women Writers and the Association of Children's Writers were abolished and their members folded into it. In the following decades, building on the communist regime's attention to print culture, the organization monopolized access to, as well as the definition of, the literary profession. It amassed members and wealth, while its publications (periodicals, literary studies, and recollections) popularized the notion of literature as the primary vessel of national identity. Not surprisingly, even recent studies that rely on sources produced by writers in the interwar and postwar periods continue to assess Bulgarian culture as literocentric. ${ }^{113}$ They continue to take at face value the self-promoted myth of "the writer as a national hero."

It bears stressing that it is not the significance of literature to the national "imagined community" that is questioned here but rather the existence of a particular east European veneration of the writer as the conjuror and voice of the nation. The patterns of literary consumption, the economic plight of literati and their recourse to non-literary means of expanding their appeal (from book exhibits to radio talks and banquets) reveal writers' precarious social status prior to the communist period. The Union of Bulgarian Writers and its later competitors were born out of a concerted effort to defend literature's public importance. But poets and novelists were not the only ones seeking to defend their relevance in resourceful ways. A recent study of the interwar associational life of Bulgarian artists reveals processes similar to those occurring in the literary field: sluggish markets, multiple rival societies, entrepreneurial activities, impassioned pleas to society, and finally, the creation of a single professional organization in the early 1930s in increasingly close cooperation with the Ministry of Education. Indeed, a bird's eye look at both interwar cultural life and state policies would not validate claims of writers' privileged position. ${ }^{114}$ The associations of journalists, artists, musicians, drama actors, booksellers, and publishers laid claim to the exceptionality and merit of their professions that the public sometimes bought and other times did not.

This case study thus calls for further investigation of the economic and institutional bases of cultural life in eastern Europe before the Cold War. Admittedly, this sociological approach to artistic life challenges the popular heroic model of the east European intellectual as the conscience of the people, symbolized by figures like Ivan Vazov, Czesław Miłosz, or Václav Havel. However, it illuminates forms of agency among both first-rate and

113. For example, Nina Dimitrova, Chasŭt na bŭlgarskata inteligentsiia: Bŭlgarskata inteligentsiia v mezhduvoennia periodichen pechat (Sofia, 2010); and Emil Dimitrov, Pamet, iubilei, kanon.

114. Vasileva, Sŭiuz na druzhestvata; See also Anchova, "Kulturno-profesionalnite," and Vasil Zagorov, "Borba za otseliavane: Sistemi za knigorazporstranenie mezhdu dvete svetovni voini," in Elena Kamenova, ed., Medii, komunikatsiia, obshtestvo (Sofia, 2009), 93-108. The 1942 statistical yearbook showed artists and actors beating writers in fundraising. In 1939, the 311-member Union of Artists' Association in Bulgaria reported close to 1.04 million lv in revenues; the Union of Actors (with 354 members) had 1.2m; while the 125 members of the Writers' Union showed 290,000 lv. 
lesser-known cultural producers who did not enter the national canon but were important social actors in their day. The focus on guilds also casts new light on the international organization and etatization of cultural and intellectual life before and after 1945. As the wars and depression years ate into the middleclass's ability to patronize artistic life, cultural producers across the continent and the Atlantic had no choice but to embrace the state as a natural ally. ${ }^{115}$ Observers in interwar Bulgaria certainly did not perceive the push of unions for state assistance as nationally unique. Literary and cultural periodicals regularly published information about sister associations and various state cultural initiatives in Italy, Belgium, Weimar and Nazi Germany, France, and the United States, as well as the Soviet Union. In other words, decisive as the Soviet model of complete control of intellectual and artistic life was, it took hold so quickly in Bulgaria and elsewhere in Cold War eastern Europe because the seeds of collaboration between state institutions and cultural guilds had been laid in the previous decades.

At the same time, the continuities between the interwar and postwar years should not conceal the two eras' markedly different milieus. Returning to the useful distinction of levels of state intervention in cultural life introduced by Mabel Berezin, one can say that the interwar Bulgarian state came closer to New Deal America than Fascist Italy: in the 1930s, both practiced a "cultural protectionism" that allowed producers to organize freely but assisted in the distribution of cultural products. ${ }^{116}$ While it intervened legislatively and institutionally in an unfavorable market to buoy the Bulgarian book, the interwar state largely left mainstream authors alone. Hence the ability of Bulgarian writers in the 1930s and early 1940s to openly protest measures of the rightwing regime, such as heightened censorship, anti-Semitic laws, or the arrest of left-wing colleagues. ${ }^{117}$ Such independence became unfeasible after the war. By the end of the 1940s, the Bulgarian communist regime had adopted the totalitarian model that centralized and directed the cultural field and kept tabs on the creation and dissemination of artistic works. In socialist Bulgaria cultural producers continued to be touted as "awakeners" but lost their intellectual freedom in a prescriptive, state-owned economy. It was ironic then that the successful myth-building of writers (and other creative groups) contributed to their confinement in what Miklós Haraszti would call later a "velvet prison." ${ }^{118}$ Licensed through their guild membership, communist-era writers enjoyed material incentives and rewards for their work, guaranteed

115. For a continent-wide exploration of the 1920s and 1930s, see Martin, The NaziFascist New Order.

116. Berezin distinguishes four variations of state control over cultural producers and cultural products: pluralism, cultural protectionism, state paternalism, and totalitarianism in "The Organization of Political Ideology," 642.

117. For example, Frederick B. Chary, “The Bulgarian Writers' Protest of October 1940 Against the Introduction of Anti-Semitic Legislation into the Kingdom of Bulgaria," East European Quarterly 4, no. 1 (March 1970), 88-93.

118. Miklós Haraszti, The Velvet Prison: Artists Under State Socialism, trans. Katalin and Stephen Landesmann (New York, 1987). 
audiences, and publications. Dissenting figures, in contrast, were marginalized and silenced in ways interwar writers never were. ${ }^{119}$

When the artificially inflated prestige of the Bulgarian writer collapsed with state socialism, it inevitably dragged down the Union of Bulgarian Writers with it. The organization fractured in 1994 over disagreements about property, heritage, political patronage, and artistic freedom. Since then, as elsewhere in Europe, writers have struggled to remain relevant. The lessons of the interwar years-from the value of professional organization to the threat of political regimes feeding on the insecurities of intellectuals and artistsmight be worth revisiting.

119. Irina Gigova, "The Feeble Charm of National(ist) Communism: Intellectuals and Cultural Politics in Zhivkov's Bulgaria," in Yana Hashamova and Theodora Dragostinova, eds. Beyond Mosque, Church, and State: Alternative Narratives of the Nation in the Balkans (Budapest, 2016), 151-77. 